\title{
An Investigation of Students' Computer Attitudes in PISA 2012 Turkey Sampling
}

\author{
Cem Oktay GÜZELLER * and Levent ERTUNA \\ Department of Measurement and Evaluation in Education, Hacettepe University \\ Ankara, Turkey
}

\begin{abstract}
The purpose of this research is to determine the students' attitudes towards computers with reference to PISA 2012 Turkey sample. The study analyzes whether the attitudes of students differ according to gender, school type, region and time spent on the internet at home and at school both on weekdays and at the weekends. It is framed in the form of a descriptive survey research. The sample consists of 4538 15-year-old Turkish students who took PISA 2012. The data was collected through the two-dimensional Attitudes towards Computers Scale (ATTCOMPS) used in PISA 2012. As for the data analysis, firstly, a Confirmatory Factor Analysis (CFA) was administered for the construct validity of the ATTCOMPS and the two-dimensional structure of the scale consisting of the importance of the Computer as a Tool for School Learning (CATFSL) and the Limitations of the Computer as a Tool for School Learning (LCATFSL) was verified. During the second phase, Cronbach Alpha coefficient was calculated in order to measure the internal consistency of the scale. To analyze the possible significant differences among the groups in terms of students' attitudes regarding the subdimensions of ATTCOMPS, a multivariate variance analysis tool MANOVA was utilized. The findings of the research show that CATFSL did not differentiate with reference to gender whereas the LCATFSL released significant differences in favour of girls. In terms of school type, there was a significant difference only between general high schools and vocational high schools with reference to CATFSL. However, the LCATFSL released significant differences among all types of schools. With regard to the results of the region variable, there was no significant difference for CATFSL. Nonetheless, with reference to the LCATFSL, the participants in the Mediterrenean Region had the lowest attitude and there was a significant difference among the students' attitudes in Aegean, East Marmara and West Black Sea Regions. Lastly, the findings of the weekly time spent on the internet variable indicated that both CATFSL and LCATFSL release meaningful differences.
\end{abstract}

Keywords: Attitudes towards computers; PISA; gender; school type; region; internet usage duration

\footnotetext{
E Address: Hacettepe University, Education Faculty, College of Education, Department of Measurement and Evaluation in Education, Beytepe - ANKARA E-mail address: cemguzeller@ hacettepe.edu.tr
} 


\section{Introduction}

The rapid changes and developments in technology cause various transformations in societies, which have evolved based on the development of societies and affecting the profile of individuals required by the society. All these could be attained with the use of technology and its opportunities which are necessary for the revisions in education. The integration of technology with learning is possible with students' use of computers-representative of technology-in their learning environments (Holloway, 2005). However, Information Technologies (IT) facilitate students' access to various learning environments and interaction with other users (Demir ve Yurdugül, 2014). With the use of computers in teaching and learning, the attitudes of students towards computers have started to gain importance.

Attitude towards computers include all the tendencies of ideas, feelings and behaviours of an individual towards computers, their usage, computer users and impacts of computers. In other words, it is the total responses of the individual towards computers (Liao, 1999). From this aspect, the attitude towards computers is a predictor that influences computer usage and at the same time shows the inclination to use computers for learning (Myers ve Halpin, 2002). Köse and Gezer (2006) specified that attitudes towards computers are the most affective factors that ensure the effective and productive use of computers as tools for learning. The studies on this issue showed that students' attitudes towards computers are significant in achieving the target learning outcomes (Mellissen and Drent, 2008; Teo, 2006; Teo, 2008; Y1ldırım, 2000). In addition to this, such studies analyzed the attitudes towards computers according to different variables such as gender, type of school, computer usage frequency, and education level (Adalıer, 2012;Altun, 2011; Çelik and Ceylan, 2009; Güzeller, 2011; Köse and Gezer, 2006; Teo, 2008; Tezci, 2009). The results of some other studies indicated that increase in the computer experience has definite correlation with the positive attitudes towards computers (Kumar and Kumar, 2003; Yıldırım, 2000). Apart from these, researches studying the correlation between academic success and attitudes towards computers showed that there is a positive correlation between these variables (Caner et al., 2006; Üzel and Özdemir, 2008).

PISA, through its exams given every three years, measures the level of the key learning goals, knowledge and skills of 15-year-olds in OECD member countries along with other countries. PISA results matter a lot since they release the students' competencies and affective features (Schleicher, 2007). Beside students' reading skills and cognitive skills such as mathematics and science literacy, PISA assesses their affective features such as attitude, self-efficacy and self-concept which are thought to influence student success. Thanks to this exam, which is administered by Organisation for Economic Co-operation and Development (OECD), it has become possible to evaluate countries' existing academic success and make comparisons among them. As a result, policy makers has started to change their educational policies (Aydın, Erdağ and Taş, 2011; Usta, 2014). Another important issue PISA places emphasis is the variables about computer technology such as computer literacy, computer usage habits, and attitudes towards computers, which are believed to play important roles in students' futures.

Studies on the attitudes towards computers generally focus on certain issues. The literature review shows that attitudes towards computers were analyzed in the following categories. Primary education (Altun, 2011; Mellissen and Drent, 2008;), high school (Çelik and Ceylan, 2009; Köse and Gezer, 2006; Tekindal, Ertekin and Tekindal, 2010), higher education (Gökalp and Aydın, 2013; Keskin and Ertuğrul, 2010; Pektaş and Erkip, 2006) and pre- 
service teachers and teachers (Berkant, 2013; Berkant and Efendioğlu, 2011; Teo, 2008). In addition to these, within the context of PISA, an international exam, there are studies looking at the attitudes towards computers with reference to Turkey sample (Çakır, 2012; Güzeller, 2011; Şahinkayas1, 2008). However, such studies are very limited in number. Yet, analysis of attitudes towards computers in these exams which are given at certain intervals is significant in observing the improvements of countries and shaping the educational programs. In this sense, the basis of this study is to identify students' attitudes towards computers in regard to PISA 2012 Turkey sample. Therefore, within the scope of its aims, the research questions for this study were:

(1) Do students' attitudes towards computers release a significant difference in terms of gender?

(2) Do students' attitudes towards computers release a significant difference in terms of school type?

(3) Do students' attitudes towards computers release a significant difference in terms of the region they live in?

(4) Do students' attitudes towards computers release a significant difference in terms of the time spent on the internet at school and home on weekdays and at the weekends?

\section{Method}

\section{Research Model}

The present study is designed in the form of a descriptive survey research that primarily investigates the attitudes of the students who participated in PISA 2012 from Turkey according to various variables. Descriptive studies are those "that try to describe and explain "what events, objects, beings, instituions, groups ve diverse fields are" (Kaptan, 1998:59).

\section{Population and Sample}

The population of the current research consists of 485,490 students representing about 28 million students from 65 countries who participated in PISA 2012 (PISA, 2012). However, the sample included 4538 15-year-old Turkish students who participated in PISA 2012.

While 2222 (\%49) of the sample were female, 2316 (\%51) of them were male. In terms of school types, $104(\% 2.3)$ of the participants were from primary schools, $2617(\% 57.7)$ of them were from general high schools, 1748 (\%38.5) of them were from vocational high schools and lastly $68(\% 1.5)$ of them were from Police High Schools. According to Nomenclature of Territorial Units for Statistics (NUTS) of Turkey, the distribution of the participants in 12 regions was as follows. $742(\% 16.4)$ of the participants were from İstanbul Region, 179 (\%3.9) of them were from West Marmara Region, 558 (\%12.3) of them were from Aegean Region, 477 (\%10.5) of them were from East Marmara Region, 498 (\%11) of them were from West Anatolia Region, 578 (\%12.7) of them were from Mediterranean Region, 243 (\%5.4) were from Central Anatolia Region, 240 (\%5.3) of them were from West Black Sea Region, 204 (\%4.5) of them were from East Black Sea Region, 152 (\%3.3) of them were from Northeast Anatolia Region, 228 (\%5.0) of them were from Central East Anatolia Region and 439 (\%9.7) of them were from Southeast Anatolia Region. 


\section{Data Collection Tools}

The data of the study was collected through the Attitudes towards Computers Scale (ATTCOMPS), which was used in PISA 2012, and PISA 2012 student survey items evaluating the weekly time spent on the internet both at home and at school. The Attitudes towards Computers Scale (ATTCOMPS) is comprised of two dimensions: "The importance of the Computer as a Tool for School Learning (CATFSL)" and "Limitations of the Computer as a Tool for School Learning (LCATFSL)." In order to represent each dimension, the scale includes such items as "The computer is a very useful tool for my schoolwork." and "Information obtained from the Internet is generally too unreliable to be used for school assignments". Each dimension is measured with three items and the scale is designed in the form of a 4 level Likert format as "Strongly Disagree" (1), "Disagree" (2), "Agree" (3), and "Strongly Agree" (4) (OECD, 2013).

In order to evaluate the reliability of the Attitudes towards Computers Scale (ATTCOMPS), Cronbach Alfa internal consistency coefficient for each sub-dimension was calculated. According to this calculation, the result was 0.788 for the sub-dimenison of "The importance of the Computer as a Tool for School Learning (CATFSL)" and 0.768 for the "Limitations of the Computer as a Tool for School Learning (LCATFSL)." Büyüköztürk (2009) specifies that Cronbach's alpha is a lower-bound estimate of reliability. Thus, a reliability coefficient over 0,70 is sufficient for reliability. In this sense, it can be said that the scale used in this study is reliable.

A Confirmatory Factor Analysis (CFA) was employed to measure the construct validity of the Attitudes towards Computers Scale (ATTCOMPS). Confirmatory Factor Analysis (CFA) is used to measure the construct validity by testing the model of a structure which was theoritically defined (Kline, 2010). During the Confirmatory Factor Analysis (CFA), fit indices such as Chi-Square ( $\chi 2), \chi 2 /$ sd, RMSEA, RMR, GFI and AGFI are used to assess the obtained model. If the $\chi 2 / \mathrm{sd}$ ratio is 5 or less than 5 , RMR and RMSEA values are lower than 0.05 , and values of GFI AGFI are higher than .90, this signals the fit between the model and data (Kline, 2010). Table 1 displays the statistics of model-data and indices regarding the results of the Confirmatory Factor Analysis (CFA) executed for the two-dimensional structure of ATTCOMPS. Table 1 shows that it is high for model-data fit when the fit indices and statistics are considered as criteria for the Confirmatory Factor Analysis. Beside these indices, the fact that NNFI and CFI values are over .90 is the indicator of a good fit. In addition, the fact that the value of SRMR, which examines the model fitting with standardized errors, is less than 0.5 (Schermelleh-Engel, Moosbrugger, \&Müller, 2003) could provide a strong evidence of the well model fitting with the data.

Table1. Attitudes towards Computers ScaleModel-Data Fit Statistics and Indices

\begin{tabular}{ccccccccccc}
\hline$\chi^{2}$ & $\mathrm{Sd}$ & $\chi^{2} / \mathrm{sd}$ & $\mathrm{p}$ & RMSEA & RMR & SRMR & GFI & NNFI & CFI & AGFI \\
\hline 14.01 & 8 & 1.751 & 0.0815 & 0.018 & 0.010 & 0.013 & 1.00 & 1.00 & 1.00 & 0.99 \\
\hline
\end{tabular}

\section{Data Analysis}

A multivariate variance analysis (MANOVA) was used in order to depict if the dependent variables of the research, the sub-dimensions of the ATTCOMPS, release significant differences in terms of the independent variables-gender, school type, region and time spent on internet usage at school and home on weekdays and at the weekends. 
Before the multivariate variance analysis is utilized, it is necessary to test the univariate and multivariate normality, the equality of variances, multicollinearity and extreme values which are the assumptions of the analysis (Pallant, 2005). The univariate normality could be assessed in terms of the coefficient of skewness and kurtosis, and if these values are between 1 and +1 , it indicates that univariate normality is attained (Muthén ve Kaplan,1985). While the multivariate normality could be measured through a method based on the coefficient of skewness and kurtosis suggested by Mardia (1970), the fact that significance test released significant results shows the lack of multivariate normality. The equality of the covariance matrix could be tested through Box's M statistics whereas the homogenity of the variances could be analyzed through Levene's Test. If these tests do not give significant results, it is the indicator of the homogenity of variances. As to the multiple correlation, while the correlations between the independent variables changing amid 0,80 and 0,90 indicate the possibility of multiple linear-by-linear association problem, values above 0,90 are the indicators of significant multiple linear-by-linear association problem (Tabachnick ve Fidell, 2001).

The univariate normality analysis made for the ATTCOMPS' sub-dimenisons, CATFSL and LCATFSL, showed that skewness and kurtosis values changed between -1 and +1 . However, the multivariate normality tests administered for these variables released statistically significant results and showed that it does not provide multivariate normality $(\chi 2=282726$, $\mathrm{p}<0.05)$. Hair et al. (2014) argued that in case of a situation when the multivariate assumption necessary for MANOVA is not provided, the test is slightly influenced if the sample size is large. Thus, the analysis was continued. As for the multicollinearity, the correlation coefficient among the variables were examined and the calculated value was 0.132 . This value illustrates that there is no multivariate correlation problem among the variables. The equality of covariance matrixes, another assumption, was analyzed separately for each research question and the results gave significant differences. Tabachnick and Fidell (2001) marked that Box's M statistics is influenced from the number of components in a unit and large samples and thus could be disregarded in such cases. Therefore, the analysis was continued. Since using Pillai's Trace value instead of Wilk's Lambda is more suitable, this statistics was administered (Can, 2013). The homogenity of the variances was measured by Levene Test, but gave no significant results. Tamhane T2 Test, which is more stable when the variances are not equal and the number of the components in the tested units are not equal, was utilized and multiple comparisons were made (Hochberg ve Tamhane, 1987). The last assumption of the Manova analysis is that it is independent from extreme values. The examination proved that the data set included no extreme values. In addition to these, the effect size could be studied in order to figure out the effectiveness of independent variables on dependent variables. According to the value obtained, Cohen (1988) interpreted the effect size as "low level effect" for $0.01 \leq \eta 2 \leq 0.06$, "medium level effect" for $0.06 \leq \eta 2 \leq 0.14$, and lastly, for $0.14<\eta 2$ "high level effect."

\section{Findings}

The first part of this chapter includes the descriptive statistics regarding the dependent and independent variables and the second part provides the results of the analysis regarding the research questions. Table 2 displays the results of the arithmetic mean and standard deviation calculated for dependent and independent variables. 
Table 2. Descriptive Statistics of the Variables

\begin{tabular}{|c|c|c|c|c|c|}
\hline \multirow{2}{*}{$\begin{array}{l}\text { Independent } \\
\text { Variables }\end{array}$} & \multirow{2}{*}{ Categories } & \multicolumn{2}{|c|}{ CATFSL } & \multicolumn{2}{|c|}{ LCATFSL } \\
\hline & & Mean & Std. D. & Mean & Std. D. \\
\hline \multirow{2}{*}{ Gender } & 1. Female & 5.026 & 0.040 & 8.265 & 0.047 \\
\hline & 2. Male & 5.124 & 0.043 & 7.570 & 0.052 \\
\hline \multirow{4}{*}{ School Type } & 1. Primary School & 4.894 & 0.178 & 6.971 & 0.264 \\
\hline & 2. General High School & 5.161 & 0.039 & 8.196 & 0.045 \\
\hline & 3. Vocational High School & 4.975 & 0.047 & 7.488 & 0.059 \\
\hline & 4. Police High Schools & 4.662 & 0.214 & 9.191 & 0.226 \\
\hline \multirow{12}{*}{ Region } & 1. TR1-İstanbul & 5.094 & 0.073 & 7.956 & 0.088 \\
\hline & 2. TR2-West Marmara & 5.028 & 0.134 & 8.000 & 0.174 \\
\hline & 3. TR3-Aegean & 4.995 & 0.084 & 8.145 & 0.096 \\
\hline & 4. TR4-East Marmara & 5.157 & 0.092 & 8.164 & 0.108 \\
\hline & 5. TR5-West Anatolia & 5.104 & 0.087 & 7.821 & 0.106 \\
\hline & 6. TR6-Mediterranean & 4.974 & 0.078 & 7.555 & 0.101 \\
\hline & 7. TR7-Central Anatolia & 5.078 & 0.126 & 8.095 & 0.146 \\
\hline & 8. TR8-West Black Sea & 5.063 & 0.126 & 8.238 & 0.144 \\
\hline & 9. TR9-East Black Sea & 4.858 & 0.128 & 7.951 & 0.167 \\
\hline & 10.TRA-North East Anatolia & 4.875 & 0.152 & 7.842 & 0.208 \\
\hline & 11.TRB-Central East Anatolia & 5.189 & 0.145 & 7.706 & 0.176 \\
\hline & 12.TRC-Southeast Anatolia & 5.298 & 0.107 & 7.620 & 0.126 \\
\hline \multirow{7}{*}{$\begin{array}{l}\text { Time spent on } \\
\text { internet usage at } \\
\text { school }\end{array}$} & 1. No time & 5.224 & 0.039 & 7.971 & 0.045 \\
\hline & 2. 1-30 minutes & 4.811 & 0.057 & 7.882 & 0.081 \\
\hline & 3. 31-60 minutes & 4.908 & 0.109 & 8.096 & 0.139 \\
\hline & 4. $1-2$ hour/s & 4.822 & 0.109 & 7.577 & 0.150 \\
\hline & 5. 2-4 hours & 4.861 & 0.179 & 7.444 & 0.216 \\
\hline & 6. 4-6 hours & 4.750 & 0.344 & 7.769 & 0.448 \\
\hline & 7. More than 6 hours & 4.959 & 0.354 & 7.020 & 0.400 \\
\hline \multirow{7}{*}{$\begin{array}{l}\text { Time spent on } \\
\text { internet usage at } \\
\text { home on } \\
\text { weekdays }\end{array}$} & 1. No time & 5.369 & 0.070 & 7.860 & 0.078 \\
\hline & 2. 1-30 minutes & 5.264 & 0.064 & 7.665 & 0.075 \\
\hline & 3. 31-60 minutes & 5.019 & 0.071 & 8.153 & 0.085 \\
\hline & 4. $1-2$ hour/s & 4.857 & 0.056 & 8.101 & 0.072 \\
\hline & 5. 2-4 hours & 4.835 & 0.081 & 7.956 & 0.109 \\
\hline & 6. 4-6 hours & 4.872 & 0.157 & 7.733 & 0.219 \\
\hline & 7. More than 6 hours & 4.958 & 0.209 & 7.135 & 0.257 \\
\hline \multirow{7}{*}{$\begin{array}{l}\text { Time spent on } \\
\text { internet usage at } \\
\text { home at the } \\
\text { weekends }\end{array}$} & 1. No time & 5.327 & 0.084 & 7.648 & 0.094 \\
\hline & 2. 1-30 minutes & 5.288 & 0.072 & 7.554 & 0.084 \\
\hline & 3. 31-60 minutes & 5.239 & 0.087 & 7.740 & 0.102 \\
\hline & 4. $1-2$ hour/s & 4.969 & 0.056 & 8.165 & 0.067 \\
\hline & 5. 2-4 hours & 4.903 & 0.064 & 8.212 & 0.082 \\
\hline & 6. 4-6 hours & 4.766 & 0.096 & 8.056 & 0.137 \\
\hline & 7. More than 6 hours & 4.920 & 0.150 & 7.624 & 0.187 \\
\hline
\end{tabular}

Table 3 illustrates the results of MANOVA Analysis which was carried out in accordance with the research aims

Table3. MANOVA Results for the sub-dimensions of ATTCOMPS and independent variables.

\begin{tabular}{lcccccc}
\hline & $\begin{array}{c}\text { Pillai's } \\
\text { Trace }\end{array}$ & F & $\begin{array}{c}\text { Hyp. } \\
\text { Df. }\end{array}$ & $\begin{array}{c}\text { Error } \\
\text { Df. }\end{array}$ & p & $\eta^{2}$ \\
\hline Gender & 0.230 & 52.538 & 2 & 4535 & 0.000 & 0.230 \\
School Type & 0.030 & 22,696 & 6 & 9068 & 0.000 & 0.015 \\
Region & 0.012 & 2.457 & 22 & 9052 & 0.000 & 0.006 \\
Internet Usage at School & 0.013 & 4.986 & 12 & 9062 & 0.000 & 0.007 \\
Int. Usage at Home on Weekdays & 0.022 & 8.317 & 12 & 9062 & 0.000 & 0.011 \\
Int. Usage at Home at Weekends & 0.025 & 9.594 & 12 & 9062 & 0.000 & 0.013 \\
\hline
\end{tabular}

The analysis of Table 3 releases the following results for the sub-dimensions of ATTCOMPS. Gender (Pillai's Trace $=.230, \mathrm{~F}(2,4535)=52.538, \mathrm{p}<.01$ ), school type (Pillai's Trace $=.030$, $\mathrm{F}(6,9068)=22.696, \mathrm{p}<.01$ ), Region (Pillai's Trace $=.012, \mathrm{~F}(22,9052)=2.457, \mathrm{p}<.01$ ), time 
spent on the internet at school (Pillai's Trace $=.013, \mathrm{~F}(12,9062)=4.986, \mathrm{p}<.01$ ), time spent on internet usage at home on weekdays (Pillai's Trace $=.022, \mathrm{~F}(12,9062)=8.317, \mathrm{p}<.01$ ) and time spent on internet usage at home at the weekends (Pillai's Trace $=.025, \mathrm{~F}(12,9062)=9.594$, $\mathrm{p}<.01$ ), showing a significant difference. Table 4 displays the results of the analysis utilized to depict which sub-dimensions have these differences.

Table 4. Variance Analysis Results of the Independent Variables

\begin{tabular}{llccccccc}
\hline $\begin{array}{l}\text { Independent } \\
\text { Variable }\end{array}$ & $\begin{array}{l}\text { ATTCOMP } \\
\text { S Dim. }\end{array}$ & $\begin{array}{c}\text { Sum of } \\
\text { Squares }\end{array}$ & Sd & $\begin{array}{c}\text { Mean } \\
\text { Square }\end{array}$ & F & $p$ & $\eta^{2}$ & Significant Difference \\
\hline \multirow{2}{*}{ Gender } & CATFSL & 10.755 & 1 & 10.755 & 2.732 & 0.098 & 0.001 & - \\
& LCATFSL & 547.250 & 1 & 547.250 & 95.946 & 0.000 & 0.021 & $1-2$ \\
\hline \multirow{2}{*}{ School Type } & CATFSL & 52.022 & 3 & 17.341 & 4.413 & 0.004 & 0.003 & $2-3$ \\
& LCATFSL & 729.858 & 3 & 243.286 & 42.938 & 0.000 & 0.028 & $1-2,3,4 ; 2-3,4 ; 3-4$ \\
\hline \multirow{2}{*}{ Region } & CATFSL & 54.416 & 11 & 4.947 & 1.257 & 0.243 & 0.003 & - \\
& LCATFSL & 222.687 & 11 & 20.244 & 3.498 & 0.000 & 0.008 & $3,4,5-6$ \\
\hline Int. Usage at & CATFSL & 165.004 & 6 & 27.501 & 7.038 & 0.000 & 0.009 & $1-2,4$ \\
School & LCATFSL & 117.949 & 6 & 19.658 & 3.387 & 0.002 & 0.004 & - \\
\hline Int. Usage at & CATFSL & 211.829 & 6 & 35.305 & 9.059 & 0.000 & 0.012 & $1-3,4,5 ; 2-3,4$ \\
home on & LCATFSL & 219.149 & 6 & 36.525 & 6.317 & 0.000 & 0.008 & $2-3,4 ; 3-7 ; 4-7$ \\
Weekdays & CATFSL & 171.683 & 6 & 28.614 & 7.326 & 0.000 & 0.010 & $1-4,5,6 ; 2-4,5,6 ; 3-5,6$ \\
\hline $\begin{array}{l}\text { Int. Usage at } \\
\text { Home at the }\end{array}$ & LCATFSL & 333.562 & 6 & 55.594 & 9.656 & 0.000 & 0.013 & $1-4,5 ; 2-4,5,6 ; 3-4,5$ \\
\hline
\end{tabular}

Table 4 shows that the sub-dimensions of ATTCOMPS release statistically significant differences. However, there is no significant difference as to the limitations of internet usage as a tool for school learning in regard to gender and region. In order to identify the source of the differences, Tamhane T2 Test was administered for each variable apart from the gender variable. With regard to the LCATFSL, which released significant difference in terms of gender, the value of the attitude of female participants $(X=8.265)$ was higher than that of male participants $(X=7.570)$. However, this difference has a small effect size.

With regard to the school types, there was a significant difference between general high schools and vocational high schools in terms of the importance of the Computer as a Tool for School Learning. However, there were significant differences among all school types in terms of the Limitations of the Computer as a Tool for School Learning. Although the difference regarding the importance of CATFSL is not significant in practice, the difference regarding the LCATFSL is slightly effective in practice.

As to the regions, the attitudes of the students towards computer released no significant difference in terms of the importance of CATFSL. Nonetheless, in terms of the LCATFSL, there were meaningful differences between Mediterranean Region and Aegean, East Marmara and West Black Sea Regions, which was to the detriment of Mediterranean Region. The differences found among regions regarding the two dimensions do not influence the practice.

According to the analysis of the last variable, time spent on internet usage, there was a significant difference between the attitudes of the students who spend no time on the internet and who spend 1-30 minutes and 1-2 hours in terms of the importance of CATFSL. In terms of the LCATFSL, there was no significant difference. As to the time spent on the internet at home on weekdays, there were statistical differences in terms of the importance of CATFSL. The results were: the difference between those who spend no time on the internet and those 
who spend 31-60 minutes, 1-2 hours and 2-4 hours and the difference between those who spend 1-30 minutes and 1-2 hours and 2-4 hours. Similarly, the attitudes of students differentiate regarding the time spent on the internet at home at the weekends. The results revealed the followings: the difference between those who spend no time on the internet and those who spend 1-2 hours, 2-4 hours and 4-6 hours. The difference between those who spend 1-30 minutes and those who spend 1-2 hours, 2-4 hours and 4-6 hours and the difference between those who spend 31-60 minutes and those who spend 2-4 hours and 4-6 hours. Likewise, in terms of the LCATFSL, the results gave statistical differences regarding the time spent on the internet at home on weekdays. The results are as follows: the difference between those who spend 1-30 minutes and those who spend 31-60 minutes and 1-2 hours and the difference between those who spend more than 6 hours and those who spend 31-60 minutes and 1-2 hours. Also, the attitudes of students released differences regarding the time spent on the internet at home at the weekends. The results were the difference between those who spend no time and those who spend 1-2 hours and 2-4 hours. The difference between those who spend 1-30 minutes and those who spend 1-2 hours, 2-4 hours and 4-6 hours and the difference between those who spend 31-60 minutes and those who spend 1-2 hours and 2-4 hours. When the impact of these variables are taken into consideration, differences regarding the importance of CATFSL on weekdays and both CATFSL and LCATFSL at the weekends have small effects, but the other meaningful differences are not significant in practice.

\section{Discussion, Result and Suggestions}

The main aim of the current study is to identify the attitudes of students towards computer with reference to PISA 2012 Turkey Sample. In this context, the differences among students' attitudes were analyzed in terms of gender, school type, region and time spent on internet usage at school and at home (both on weekdays and at the weekends). As to the gender variable, the results showed that there is no significant difference regarding the importance of CATFSL, but there is a significant difference for the advantage of female students regarding the LCATFSL. Findings as to the importance of CATFSL are similar with those Şerefhanoğlu, Nakiboğlu and Gür (2008) revealed for primary education students, those Köse and Gezer (2006), Çelik and Ceylan (2009) found for high school students and Teo (2008),Tezci (2009) and Adalier (2012) indicated for pre-service teachers. However, the studies of Çakır (2012) and Güzeller (2011) on PISA samples revealed significant differences in favour of male students' attitudes towards computers. Similarly, the studies of Altun (2011), Üzel and Özdemir (2008), Gürbüzoğlu-Yalmancı and Aydın (2014) with primary school students and Tekindal, Ertekin and Tekindal (2010) with high school students gave similar results. Moreover, the study of Çelik and Ceylan (2009) brought about significant differences in favour of female students. The difference in favour of female students regarding the importance of CATFSL shows that they consider computers limited, namely, they do not trust computers adequately. This, as Altun (2011) depicted, might result from the fact that girls spend less time on computers than boys or they are less interested in such activities as computer games than boys. However, this finding might be a result of girls' not sparing time on technology as required by the roles Turkish society lay on them and also their traditional attitudes, namely resistance towards changes because of the way they are raised.

The analysis of school types revealed significant differences in favour of general high schools over vocational high schools in terms of the importance of CATFSL. However, there is a significant difference among all school types in terms of the LCATFSL. Likewise, the study 
of Güzeller (2011) revealed that the attitudes of students in vocational high schools were lower than those in general high schools. On the other hand, Çelik and Ceylan (2009) found no significant difference in the attitudes of students towards computers in general high schools, Anatolian High School Anatolian teacher training high schools and Science high schools. These significant differences might result from the fact that students are accepted to these schools based on their success levels and the profile of students in each school type differentiates.

The findings of the region variable released no significant differences with regard to the importance of CATFSL. However, in terms of the LCATFSL, the least positive attitude towards computers was found in Mediterranean Region and there were significant differences among the participants of Aegean, East Marmara and West Black Sea Regions. The findings regarding the importance of CATFSL differ from those of Güzeller (2011). By contrast with this, Karakaya (2010), who in his study compared the attitudes of English Language teachers towards computers, found that their attitudes do not differ in accordance with the geographical regions. The reason that there is no difference among the regions in terms of the importance of CATFSL might be due to all students' easy access to computers thanks to the expansion of technology. However, regarding the LCATFSL, the finding that attitudes of students in the Mediterranean Region are less positive could be interpreted as these students have less negative attitudes towards the limitations of computer as a tool for school learning. The fact that the region is developed in terms of tourism and thus there is more integration with the foreign tourists and also there are more foreign students at schools might have brought in this result.

When the students' attitudes towards computers are analyzed in terms of the time they spend on the internet at school and at home, the findings differ regarding the sub-dimensions of the importance of CATFSL and the LCATFSL. According to this, with regard to the importance of CATFSL, there is a difference in favour of those who have no time over those who spend some time on the internet. That is, these students have more positive attitudes towards computers than others. With regard to the LCATFSL, there is no difference. The difference for the advantage of those students who have no time is remarkable. The findings regarding the internet usage on weekdays and at the weekends with reference to the importance of CATFSL and the LCATFSL reveal significant differences in favour of no usage and 130minute usage over others. Although this could not be generalized, less internet usage at home increases the idea of the importance of computer as a tool for learning. On the other hand, the findings showed that students who spend more time on the internet (1 hour or more) trust the internet for learning purposes more than those who spend no time or less than 1 hour on the internet. This complies with Altun's (2011) finding which indicates that the more the internet is used, the more positive are the attitudes towards computers. With regard to the LCATFSL dimension, supporting the findings for the importance of CATFSL, if the time spent on the internet especially at the weekends surpasses 1 hour, the claims regarding the limitations of computer for learning increase.

The findings of this research indicate that the attitudes of the students who participated in PISA 2012 from Turkey towards computer usage for learning differentiate with regard to gender, school type, regions and time spent on the internet at school and at home. In this sense, in terms of the gender variable, prejudices of female students towards the limitations of computer for school learning should be eliminated. Even though there are slight differences regarding the school type variable, these results are the indicators of uneven distribution of 
projects which were the government policies aiming to increase the computer usage at schools. This contradicts with the principle of equality in a social state. The findings regarding the time students spend on the internet at home in a week reveal that the more time spent on the internet does not sufficiently influence the attitudes and in fact has an adverse effect. This shows that students are not adequately informed and guided about internet usage. As a result, it can be concluded that since the projects of the government are not administered efficiently, revisions that could decrease the differences among school types and increase the efficiency of internet usage should be made in educational policies.

\section{References}

Adalıer, A. (2012). Turkish and English Language Teacher Candidates' Perceived Computer SelfEfficacy and Attitudes Toward Computer. The Turkish Online Journal of Educational Technology, 11(1), 192- 201.

Altun, T. (2011). İlköğretim öğrencilerinin bilgisayara yönelik tutumlarının incelenmesi: Trabzon ili örneği. Turkish Journal of Computer and Mathematics Education, 2(1), 6986.

Aydın, A., Erdağ, Ç. ve Taş, N. (2011). 2003-2006 PISA okuma becerileri sonuçlarının karşılaştırmalı olarak değerlendirilmesi: en başarılı beş ülke ve Türkiye. Kuram ve Uygulamada Ĕ̈itim Bilimleri Dergisi,11, 665-673.

Berkant, H. G. (2013). Öğretmen Adaylarının Bilgisayara Yönelik Tutumlarının ve ÖzYeterlik Algılarının ve Bilgisayar Destekli Eğitim Yapmaya Yönelik Tutumlarının Bazı Değişkenler Açısından İncelenmesi. The Journal of Instructional Technologies \&Teacher Education, 3,11-22.

Berkant, H. G. \& Efendioğlu, A. (May, 2011). Faculty of education students' attitudes toward computer and making computer supported education. Paper presented at International Educational Technology Conference (IETC) 2011, 25-27 May 2011, Istanbul, Turkey, (pp. 543-548).

Büyüköztürk, Ş.(2009). Sosyal Bilimler için Veri Analizi El Kitabı İstatistik, Araştırma Deseni SPSS Uygulamalarl ve Yorum (10.Baskl). Ankara: PegemA Yayınc1lık.

Can, A. (2013). SPSS ile bilimsel araştırma sürecinde nicel veri analizi. (Birinci Baskı). Ankara: Pegem Akademi.

Caner, H., Civelek, A., Özder, H., \& Güzer, B., (2006). Ortaöğretim öğrencilerinin bilgisayara yönelik tutumları ile akademik başarıları arasındaki ilişki. 7. Ĕ̈̆itim Teknolojileri Kongresi, Doğu Akdeniz Üniversitesi.

Cohen, J.(1988). Statistical power analysis for the behavioral sciences (2nd ed.). Hillsdale, NJ: Lawrence Earlbaum Associates.

Çakır, O. (2012). Students' self confidence and attitude regarding computer: An international analysis based on computer availability and gender factor. Social and Behavioral Sciences, 47, 1017 - 1022.

Çelik, H.C. ve Ceylan, H. (2009). Lise Öğrencilerinin Matematik ve Bilgisayar Tutumlarının Çeşitli Değiş̧kenler Açısından Karşılaştırılması. Pamukkale Üniversitesi Eğitim Fakültesi Dergisi, 26, 92-101.

Demir, Ö. ve Yurdugül, H. (2014). Ortaokul ve lise öğrencileri için bilgisayara yönelik tutum ölçeğinin Türkçe'ye uyarlanması. Eğitim ve Bilim, 39(176).

Gökalp, S., \& Aydın, T. (2013). Teknik program öğrencilerinin bilgisayar ve internet kullanımına yönelik tutumlarının analizi. Bülent Ecevit Üniversitesi Fen Bilimleri Dergisi, 2 (2), 127-134. 
Gürbüzoğlu-Yalmancı, S. ve Aydın, S. (2014). Ortaokul öğrencilerinin teknolojiye yönelik tutumlarının bazı değişkenler açısından incelenmesi, Ege Eğitim Dergisi, (15)1, 125 138.

Güzeller, O.C. (2011). PISA 2009 Türkiye örnekleminde öğrencilerin bilgisayar öz-yeterlik inançları ve bilgisayar tutumları arasındaki ilişkinin incelenmesi. Ahi Evran Üniversitesi Kırşehir Ĕgitim Fakültesi Dergisi (KEFAD), 12 (4), 183-203.

Hair, J. F., William, Jr., Black, C., Babin, B. J., and Anderson, R. E. (2014). Multivariate data analysis (Seventh Ed.). London: Pearson Publications. New York: Springer Science+Business Media.

Hochberg Y.\& Tamhane, A.C. (1987). Multiple comparison procedures. New York: John Wiley \& Sons press.

Holloway, S. D. (2005). Increasing technology integration throuh collaboration between media specialists and teachers. Retrived from http://teach.valdosta.edu/are/vol4no1/pdf/HollowaySArticle_0426.pdf

Kaptan, S. (1998). Bilimsel araştırma ve istatistik teknikleri (11.Baskı). Ankara: Tek Işık Web Ofset.

Karakaya, K. (2010). An investigation of English language teachers' attitudes toward computer technology and their use of technology in language teaching. (Unpublished masteres thesis). Middle East Technical University, Ankara.

Keskin, N., \& Ertuğrul, İ. (2010). Buldan MYO Büro Yönetimi Öğrencilerinin bilgisayar kullanımına yönelik tutumlarının belirlenmesine ilişkin alan çalışması. Uluslararası İktisadi ve İdari Incelemeler Dergisi, 3 (59), 1-20.

Kline, R.B. (2010). Principles and practice of structural equation modeling (Third Edition). New York: Guilford Press.

Köse, S. ve Gezer, K. (2006). Buldan (Denizli) ilçesi lise öğrencilerinin bilgisayara yönelik tutumları. Buldan Sempozyumunda sunulmuş sözlü bildiri. Pamukkale Üniversitesi, T.C. Buldan Kaymakamlığı, Buldan Belediyesi, Denizli.

Kumar, P. ve Kumar, A. (2003). Effect of a web-based project on preservice and inservice teachers' attitude toward computers and their technology skills. Journal of Computing in Teacher Education, 19(3), 87-92.

Liao, Y.-K. C. (1999). Gender differences on attitudes toward computers: A meta analysis. Society For Information Technology \& Teacher Education International Conferance. San Antonio.

Mardia, K. V. (1970). Measures of multivariate skewness and kurtosis with applications. Biometrika, 57, 519-530.

Meelissen, M. ve Drent, M. (2008). Gender differences in computer attitudes: Does the school matter? Computers in Human Behavior, 24(3), 969-985.

Muthen, B. \& Kaplan, D. (1985). A comparison of some methodologies for the factor analysis of non-normal Likert variables. British Journal of Mathematical and Statistical Psychology, 38, 171-189.

Myers, J. M. ve Halpin, R. (2002). Teachers' attitudes and use of multimedia technology in the classroom: Constructivist-based professional development training for school districts. Journal of Computing in Teacher Education, 18(4), 133-140.

OECD (2013), PISA 2012 Assessment and Analytical Framework: Mathematics, Reading, Science, Problem Solving and Financial Literacy. Erişildi http://www.oecdilibrary.org/education/pisa-2012-assessment-and-analyticalframework_9789264190511-en 
Pallant, J. (2005). SPSS Survival Manual: A Step by Step Gulde to Data Analysis Using SPSS for Windows. Australia: Australian Copyright.

Pektaş, Ş. T. \& Erkip, F. (2006). Attitudes of design students toward computer usage in design. International Journal of Technology and Design Education, 16(1), 79-95.

PISA. (2012). Student questionnaire data file. Retrieved from http://pisa2012.acer.edu.au/downloads. php

Schermelleh-Engel, K., Moosbrugger, H., \& Müller, H. (2003). Evaluating the fit of structural equation models: Test of significance and descriptive goodness-of-fit measures. Methods of Psychological Research-Online, 8 (2), 23-74.

Schleicher, A. (2007). Can competencies assessed by PISA be considered the fundamental school knowledge 15 year olds should possess? Journal of Educational Change, 349357.

Şahinkayası, Y. (2008). A cross-cultural comparison modeling of information and communication technologies aspects affecting mathematical and problem solving literacy and perceptions of policy makers. (Unpublished doctoral dissertation). Orta Doğu Teknik University, Ankara, Turkey.

Şerefhanoğlu, H., Nakiboğlu, C. \& Gür, H. (2008). İlköğretim ikinci kademe öğrencilerinin bilgisayara yönelik tutumlarının çeşitli değişkenler açısından incelenmesi: Balıkesir örneği. İlkögretim Online, 7 (3): 785-799.

Tabachnick, B. G. \& Fidell, L. S. (2001). Using Multivariate Statistics (Forth Ed.). London: Pearson.

Tekindal, B., Ertekin, A.R. \& Tekindal, M.A. (2010). Meslek Liselerinde Eğitim-Öğretim Gören Örgencilerin Bilgisayara Yönelik Tutumlarının Değerlendirilmesi (Yozgat ili Yerköy ilçesi Örneği). Bilişim Teknolojileri Dergisi, 3 (1), 23-30.

Teo, T. (2006). Attitudes toward computers: A study of post-secondary students in Singapore. Interactive Learning Environments, 14(1), 17-24.

Teo, T. (2008). Pre-service teachers ${ }^{\text {ee }}$ attitudes towards computer use: A Singapore survey, Australasian Journal of Educational Technology, 24(4):413-424.

Tezci, E. (2009) Teacherse effect on ict use in education: the Turkey sample, Procedia Social and Behavioral Sciences, 1, pp. 1285-1294.

Usta, H., G. (2014). PISA 2003 ve PISA 2012 matematik okuryazarlığı üzerine uluslararası bir karşılaştırma: Türkiye ve Finlandiya. Unpublished doctoral dissertation, Ankara Üniversitesi, Ankara, Turkey.

Üzel, D. ve Özdemir, E. (2008). İlköğretim Matematik Öğretmenliği (İMÖ) Öğrencilerinin Bilgisayara Yönelik Tutumlarıyla Öğrencilerin Başarılarının İncelenmesi. 8th International Educational Technology Conference, Anadolu Üniversitesi, Eskişehir, 6-9 Mayıs 2008, 274-279.

Y1ldirım, S. (2000). Effects of an educational computing course on pre-service and in-service teachers: A discussion and analysis of attitudes and use. Journal of Research on Computing in Education, 32(4), 479-495. 